\section{Los clubes políticos en Tucumán. Discursos, representaciones y prácticas}

María José Navajas
María José Navajas es Investigadora adscripta del Instituto de Estudios Socioeconómicos, Facultad de Ciencias Económicas, Universidad Nacional de Tucumán.

e-mail: maria_jose_navajas@yahoo.com.ar

\section{Resumen}

Este trabajo se ubica en el contexto de la provincia de Tucumán, en las décadas de 1860 y 1870, con el propósito de ponderar la cuestión de las representaciones y las prácticas articuladas en torno a los clubes que se organizaron en las distintas coyunturas electorales, para indagar las definiciones y conceptos del lenguaje político. Para ello se estudia la organización y desempeño de los clubes, los tipos de discursos y representaciones que definieron su accionar en el campo político y las prácticas que promovieron. El tema de los clubes se plantea en íntima relación con el papel desempeñado por la prensa política como ámbito clave para la configuración y difusión de esos discursos y representaciones. Se incluye como una cuestión importante la participación de nuevos actores en la escena pública provincial a través del espacio asociativo que brindaban los clubes. A partir del desarrollo de tales temas podrá advertirse la articulación de imágenes contrapuestas e incluso contradictorias que se resumían en los términos de club y partido, pero que aludían a las representaciones y significados inherentes a la política decimonónica.

\section{Summary}

This work is located in the context of Tucumán's province, during the decades of 1860 and 1870 . The aim is to examine the question of the representations and the practices articulated around the clubs that were organized in the different electoral conjunctures, to investigate the definitions and concepts of the political language. From this approach, the proposal is to examine the organization and performance of the clubs, the types of speeches and representations that defined their behavior in the political field and the practices that they promoted. The topic of the clubs appears in intimate relation with the role played by the political press as key area for the configuration and diffusion of these speeches and representations. Likewise, there is included as an important question the participation of new actors in the public provincial scene through the associative space that the clubs were offering. From the development of such topics it will be noticed the opposite and even contradictory images built and summarized around the terms of club and party, that allude to representations and inherent meanings to the nineteenth-century politics. 